\title{
Poor-Soil Rhizosphere Enriched with Different Microbial Activities Influence the Availability of Base Elements
}

\author{
Faten Dhawi ${ }^{1}$, Anna Hess ${ }^{2}$ \\ ${ }^{1}$ Biotechnology Department, King Faisal University, Al-Hofuf, Al-Ahsa, Saudi Arabia \\ ${ }^{2}$ Minnesota Department of Natural Resources, Division of Ecological and Water Resources, Duluth, USA \\ Email:dr.faten.dhawi@gmail.com,falmuhanna@kfu.edu.sa, Anna.hess@state.mn.us
}

How to cite this paper: Dhawi, F. and Hess, A. (2017) Poor-Soil Rhizosphere Enriched with Different Microbial Activities Influence the Availability of Base Elements. Open Journal of Ecology, 7, 495502.

https://doi.org/10.4236/oje.2017.78033

Received: July 1, 2017

Accepted: July 31, 2017

Published: August 3, 2017

Copyright (c) 2017 by authors and Scientific Research Publishing Inc. This work is licensed under the Creative Commons Attribution International License (CC BY 4.0).

http://creativecommons.org/licenses/by/4.0/

\begin{abstract}
Understanding the ecology of soil rhizosphere is essential to enhancing soil ecosystem and plants productivity. Poor-soil properties can limit rhizosphere microbial composition, interactions and plants productivity. Furthermore, the presence of plant exudates and microbial interation can change the rhizosphere dynamic. In the current study, we used two types of soils, rich nutrient soil represented by potting-soil and poor-soil represented with nutrientdeprived poor-soil. The two types of soil were inoculated with five microbial combinations using plant growth promoting bacteria (PGPB, Pseudomonas fluorescens) and mycorrhiza, and planted with two-day-old sorghum bicolor and Setaria italica (Foxtail millet) seedlings. Soil elements analyses were conducted 60 days after planting. The availability of exchangeable base alkali elements $(\mathrm{Ca}, \mathrm{Mg}, \mathrm{Na})$ were measured and compared. Na was exclusively affected by PGPB inoculation in both soil types. $\mathrm{Ca}$ and $\mathrm{Mg}$ increased highest when associated with arbuscular inoculation, exclusively, in comparison to association with PGPB or Ectomycorrhiza in both soil types when planted with sorghum. Whereas, the same elements $\mathrm{Ca}$ and $\mathrm{Mg}$, increased highest when associated with arbuscular mycorrhiza inoculation whether combined with PGPB or ectomycorrhiza when in soil planted with Setaria italica. The mycorrhiza increased $\mathrm{Ca}$ and $\mathrm{Mg}$ availability when combined with PGPB. Naincrease was associated only with PGPB inoculation solely in both soil types. The use of arbuscular mycorrhiza inoculation combined with PGPB is ecofriendly method to enrich rhizosphere in poor-soil and eliminate the need to use any chemical fertilizers.
\end{abstract}

\section{Keywords}

Soil, Nutrients, Pseudomonas fluorescens, Mycorrhiza, Ectomycorrhiza, Arbuscular Mycorrhiza, Glomus sp. Elements 


\section{Introduction}

The rhizosphere is the borderline between plant and microorganisms, within biological systems and soil. The rhizosphere is the borderline where interactions affect ecosystem and plant growth and productivity. Soil rhizosphere interactions involve soil microorganism and plant roots exudates. It has been reported that poor-soil nutrient content influences the microbial diversity [1] and plant biomass [2]. However, inoculating poor-soil with microbes such as Plant Growth Promoting Bacteria (PGPB) and mycorrhiza have been found to increase microbial activities and soil available elements [2]. These plant growth-promoting bacteria, such as some strains of Pseudomonas, can induce plant growth by changing the rhizosphere via volatile organic compounds [3]. Mycorrhiza was intensively studied and found to benefit soil and plant productivity and health [2] [4] [5]. Poor-soil enrichment with microorganisms increased soil organic matter and productivity of plants [6] [7]. In situations of abiotic stress, soil inoculation with arbuscular mycorrhiza alone have improved the ability of the soil to increase water use efficiency for Allium sativum L. [8]. Moreover, ectomycorrhiza have great tolerance for heavy metals in contaminated soils [9]. Inoculating soil with PGPB such as Pseudomonas fluorescens, reduced soil toxicity and increased sorghum bicolor productivity and mycorrhiza colonization growth [6]. Overall, the use of PGPB alone or combined with mycorrhiza increases soil microbial diversity and plant productivity [10]. The objective of the current study was to evaluate microbial inoculation ability to increase alkali elements availability in poor soil.

\section{Material and Methods}

In the current study, two types of soils were studied under two levels of biological root systems with six microbial combinations. At the first level, we applied six microbial combinations. The first type of soil was Potting-soil (PS) (Miracle Gro Premium Potting Mix by Scotts) distributed in pots $6 \mathrm{~kg}$ for each. The second type of soil was Poor-soil (TL), composed of soil poor in lime $(\mathrm{CaO})$, with low holding capacity, and low nutrient such as magnesium $(\mathrm{Mg})$, nitrogen $(\mathrm{Na})$, phosphate $\left(\mathrm{PO}_{3}^{4-}\right)$, and potassium $(\mathrm{K})$. The biological systems included two types of plants roots: sorghum bicolor and Setaria italica.

The soil was distributed in $(6 \times 7$ inch) pots, $6 \mathrm{~kg}$ for each with four replicates for each group. The inoculum was dissolved with water $(9 \mathrm{~g} / 100 \mathrm{ml})$ for placement in each pot. We used plant growth promoting bacteria (PGPB) Pseudomonas fluorescens obtained from microbial laboratories. The mycorrhizal mix source was MycoApply Endo (Valentine Country Inc.).

The microbial treatments were grouped as follow:

1) C-: dead inoculum but no plants were grown

2) C+: active inoculum but no plants were grown

3) PGPB: Plant growth promoting bacteria, Pseudomonas fluorescens

4) AM: 100,000 propagules/lb of Arbuscular mycorrhiza consisting of Glomus intraradices, G. mosseae, G. aggregatum and G. etunicatum. 
5) $\mathrm{AM}+$ Ecto: 100,000 propagules/lb of arbuscular mycorrhiza consisting of Glomus intraradices, G. mosseae, G. aggregatum, G. etunicatum: and ectomycorrhiza consisting of 110 million propagules/lb. of Rhizopogon villosullus, $R$. luteolus, $R$. amylogpogon, $R$. fulvigleba, Pisolithus tinctorius, Scleroderma cepa and $S$. citrinum.

6) $\mathrm{AM}+\mathrm{PGPB}: 4+3$.

7) Ecto + PGPB: 3+ ectomycorrhiza consisting of 110 million propagules/lb of Rhizopogon villosullus, $R$. luteolus, $R$. amylogpogon, $R$. fulvigleba, Pisolithus tinctorius, Scleroderma cepa and $S$. citrinum.

Two months (60 days) after growing plants with different microbial treatment, soil samples were collected and $\mathrm{Ca}, \mathrm{Mg}$ and $\mathrm{Na}$ were quantified. The availability of exchangeable base alkali elements $\mathrm{Ca}, \mathrm{Mg}, \mathrm{Na}$ were determined using Motsara and Roy method [11] and analyzed using inductively coupled plasma mass spectrometry (ICP-MS).

\section{The Experimental Design}

The experiment consisted of: two types of soils, Potting-soil (PS) and Poor-soil (TL); two types of plants, sorghum bicolor and Setaria italica; and seven groups of treatments, including $\mathrm{C}-, \mathrm{C}+, \mathrm{PGPB}, \mathrm{AM}, \mathrm{AM}+$ Ecto, $\mathrm{AM}+\mathrm{PGPB}$ and Ecto + PGPB; each with four replicates. The experimental design was $2 * 2 * 7 * 4$. The total number of pots was 112 pots for the entire experiment. Variables were tested for normality to meet assumptions. Statistical analyses included an analysis of variance (ANOVA) and Tukey's HSD test, conducted using SPSS 16. Analysis of correlation was conducted using Excel 2017. We also used the $t$-independent test to check if there was a significant difference for availability of each element ( $\mathrm{Ca}, \mathrm{Mg}$ and $\mathrm{Na}$ ) under different microbial treatments within the same soil, in comparison to positive control group in all soil types, whether planted with sorghum bicolor or Setaria italica $(\alpha=0.05)$. Analysis of $t$-independent test was conducted using SPSS 16.

\section{Results}

The ANOVA results indicated that elements availability was significantly affected by the different microbial combinations and the soil types. The significant two-way interaction based on ANOVA at $p<0.05$. Tukey's HSD test identified values indexed by different letters indicating statistically significant differences between values $(p<0.05)$. The same pattern was shown in the two plant types (sorghum bicolor and Setaria italica) indicating no significant difference between plants; however, a significant difference was found in the same plant type using different soil or different microbial combinations (Figure 1(A) and Figure 1(B)). The correlation analysis indicated a negative correlation between $\mathrm{Na}$ and $\mathrm{Mg}(-0.7)$ in poor soil and positive correlation between $\mathrm{Ca}$ and $\mathrm{Mg}(0.6)$ in potting soil planted with sorghum. Soils planted with Setaria italica indicated positive correlation (0.9) between $\mathrm{Na}$ and $\mathrm{Mg}$ in poor soil and $\mathrm{Ca}$ and $\mathrm{Mg}(0.6)$ in 


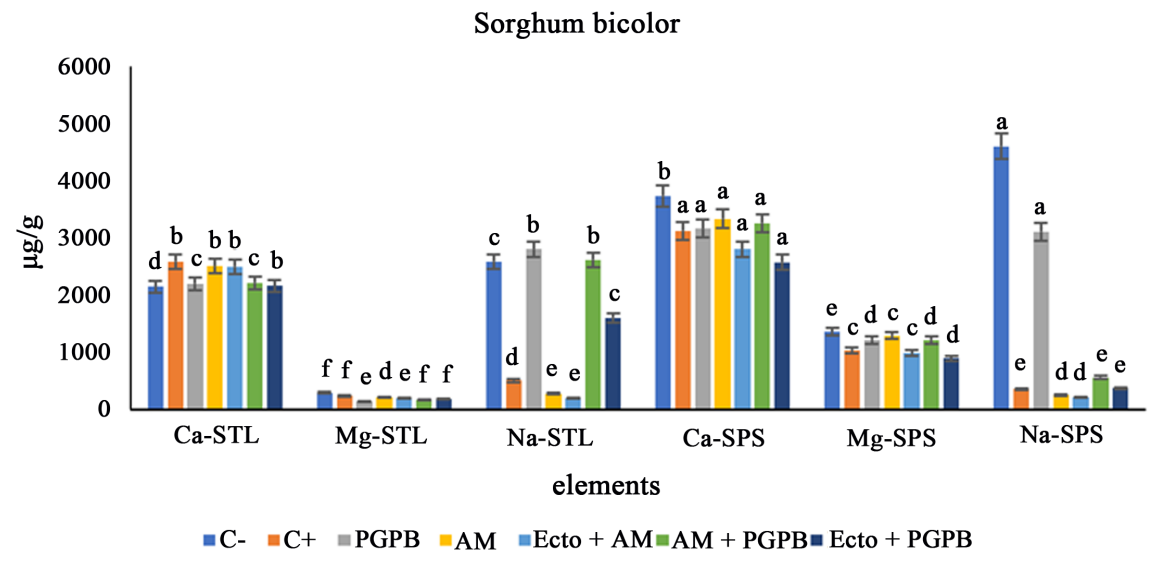

(A)

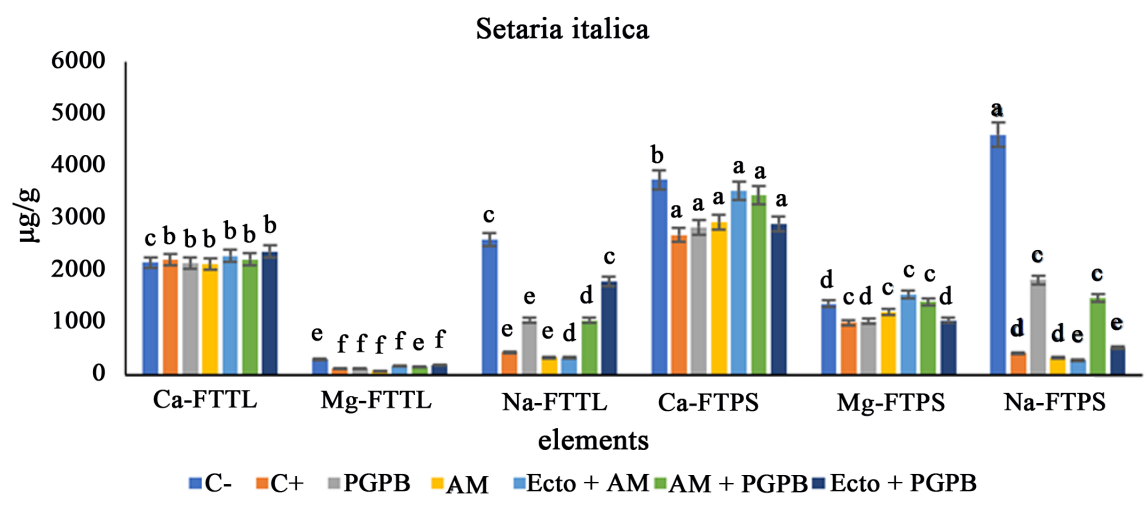

(B)

Figure 1. Effect of different of microbial groups on base elements $\mathrm{Ca}, \mathrm{Mg}, \mathrm{Na}$ availability in two types of soil (Poor soil: TL and potting soil: PS) using two plant types, (A) sorghum bicolor and (B) Setaria italica, grouped according to microbial inoculations as (C-: dead inoculum, C+: active inoculum but no plants were grown, PGPB: Pseudomonas fluorescens, AM: Arbuscular mycorrhiza, AM + Ecto: arbuscular mycorrhiza + ectomycorrhiza, Ecto + PGPB: 3+ ectomycorrhiza). Different letters are significantly different according to Tukey's test $(p<0.05)$, values are 4 replicates \pm SD.

potting soil. The $t$-independent test showed similar results with highly significance influence via PGPB and AM + PGPB groups on Na availability in all soil types. In comparison, the $\mathrm{Ca}$ availability was only significantly influenced in poor soil under the same groups (PGPB and AM + PGPB) planted with sorghum bicolor only. Lastly, Ecto + PGPB influenced Mg availability significantly in all soil types (Table 1).

Elements were compared to positive control $(\mathrm{C}+)$ to identify the percentage of change in Poor-soil (TL) or Potting-soil (PS) for the two types sorghum and Setaria italica.

In poor-soil planted with sorghum, Ca increased $96 \%$ in the two mycorrhiza groups. AM and Ecto + AM then followed with increase reached $85 \%$ in groups that were inoculated with PGPB solely or combined mycorrhiza two types. In comparison, poor-soil planted with Setaria italica, Ca reached over $100 \%$ in all 
Table 1. T independent test analysis interaction results for using different microbial combinations in comparison with positive control (C) in two types of soil (poor TL and potting soil PS), using two plant types (sorghum bicolor and Setaria italica), on availability of three elements $\mathrm{Ca}, \mathrm{Mg}$ and $\mathrm{Na}$ with significant association $(p<0.05)$.

\begin{tabular}{|c|c|c|c|c|c|c|c|c|}
\hline & Interaction & $p$ & & Interaction & $p$ & & Interaction & $p$ \\
\hline Ca-STL & $\mathrm{C}^{\star} \mathrm{PGPB}$ & 0.02 & Na-STL & $\mathrm{C}^{\star} \mathrm{PGPB}$ & 0.001 & Mg-STL & $\mathrm{C}^{\star} \mathrm{PGPB}$ & 0.01 \\
\hline Ca-SPS & & 0.44 & Na-SPS & & 0.007 & Mg-SPS & & 0.7 \\
\hline Ca-FTTL & & 0.41 & Na-FTTL & & 0.001 & Mg-FTTL & & 0.8 \\
\hline Ca-FTPS & & 0.74 & Na-FTPS & & 0.001 & Mg-FTPS & & 0.8 \\
\hline $\mathrm{Ca}-\mathrm{STL}$ & $\mathrm{C}^{\star} \mathrm{AM}$ & 0.19 & $\mathrm{Na}-\mathrm{STL}$ & $\mathrm{C}^{\star} \mathrm{AM}$ & 0.01 & Mg-STL & $\mathrm{C}^{\star} \mathrm{AM}$ & 0.16 \\
\hline Ca-SPS & & 0.57 & Na-SPS & & 0.06 & Mg-SPS & & 0.21 \\
\hline Ca-FTTL & & 0.237 & Na-FTTL & & 0.09 & Mg-FTTL & & 0.001 \\
\hline Ca-FTPS & & 0.4 & Na-FTPS & & 0.6 & Mg-FTPS & & 0.02 \\
\hline $\mathrm{Ca}-\mathrm{STL}$ & $\mathrm{C}^{\star}$ Ecto $+\mathrm{AM}$ & 0.16 & Na-STL & $\mathrm{C}^{*}$ Ecto $+\mathrm{AM}$ & 0.01 & Mg-STL & $\mathrm{C}^{\star}$ Ecto $+\mathrm{AM}$ & 0.06 \\
\hline Ca-SPS & & 0.18 & Na-SPS & & 0.028 & Mg-SPS & & 0.05 \\
\hline Ca-FTTL & & 0.8 & Na-FTTL & & 0.2 & Mg-FTTL & & 0.7 \\
\hline Ca-FTPS & & 0.7 & Na-FTPS & & 0.16 & Mg-FTPS & & 0.001 \\
\hline $\mathrm{Ca}-\mathrm{STL}$ & $\mathrm{C}^{*} \mathrm{AM}+\mathrm{PGPB}$ & 0.01 & $\mathrm{Na}-\mathrm{STL}$ & $\mathrm{C}^{*} \mathrm{AM}+\mathrm{PGPB}$ & 0.002 & Mg-STL & $\mathrm{C}^{*} \mathrm{AM}+\mathrm{PGPB}$ & 0.02 \\
\hline $\mathrm{Ca}-\mathrm{SPS}$ & & 0.4 & Na-SPS & & 0.004 & Mg-SPS & & 0.7 \\
\hline Ca-FTTL & & 0.8 & Na-FTTL & & 0.001 & Mg-FTTL & & 0.1 \\
\hline Ca-FTPS & & 0.06 & Na-FTPS & & 0.001 & Mg-FTPS & & 0.001 \\
\hline $\mathrm{Ca}-\mathrm{STL}$ & $\mathrm{C}^{\star}$ Ecto $+\mathrm{PGPB}$ & 0.01 & Na-STL & $\mathrm{C}^{\star}$ Ecto $+\mathrm{PGPB}$ & 0.02 & Mg-STL & $\mathrm{C}^{\star}$ Ecto $+\mathrm{PGPB}$ & 0.06 \\
\hline Ca-SPS & & 0.01 & $\mathrm{Na}-\mathrm{SPS}$ & & 0.4 & Mg-SPS & & 0.002 \\
\hline Ca-FTTL & & 0.3 & Na-FTTL & & 0.001 & Mg-FTTL & & 0.05 \\
\hline Ca-FTPS & & 0.5 & Na-FTPS & & 0.7 & Mg-FTPS & & 0.003 \\
\hline
\end{tabular}

the three groups AM + PGPB, Ecto + AM and Ecto + PGPB, and 96\% within $\mathrm{AM}$ and PGPB in group solely when compared to the control.

$\mathrm{Mg}$ in Poor-soil planted with sorghum showed highest increases of $88 \%$ and $83 \%$ in AM and Ecto + AM, respectively, and lowest (61\%) in PGPB.

$\mathrm{Na}$ in Poor-soil, increased over 500\% associated with PGPB group solely when planted with sorghum and over $400 \%$ in Ecto + PGPB group when planted with Setaria italica.

In Potting-soil planted with sorghum, $\mathrm{Ca}$ achieved the highest increase $(100 \%)$ in arbuscular mycorrhiza (AM or AM + PGPB) groups, and to a lesser extent of $85 \%-89 \%$ when associated with Ectomycorrhiza in Ect + AM and Ecto + PGPB. While in Potting-soil planted with Setaria italica, Ca increased over $100 \%$ to all groups with highest peak at $128 \%$ in AM + PGPB.

In Potting-soil planted with sorghum $\mathrm{Mg}$ increased $124 \%, 116 \%$ and $94 \%$ in $\mathrm{AM}$ then $\mathrm{AM}+\mathrm{PGPB}$ and Ecto $+\mathrm{AM}$ respectively. In Potting-soil planted with Setaria italica, Mg increased 153\%, 140\%, 120\% in Ecto + AM, AM + PGPB, and AM respectively. 
$\mathrm{Na}$ in Potting-soil reached the highest in PGPB group, increasing over $800 \%$ when planted with sorghum, and increasing over $400 \%$ when planted with Setaria italica. In general $\mathrm{Ca} / \mathrm{Mg}$ ratio in all groups was high (Figure $1(\mathrm{~A})$ and Figure $1(\mathrm{~B}))$.

\section{Discussion}

The microbial inoculations enriched the soil rhizosphere and made significant contributions to plants productivity and nutrient dynamic. Rhizosphere microbial activities induce the oxidation-reduction potential, influence moisture and nutrients abundance [12]. The activity of microbes in soil increase elements availability via biomineralization [13]. The use of PGPB has been reported to increase soil fertility by biomineralization organic matters in soil [14]. The biomineralization resulted from microorganism interaction with plants secrete Indol Acetic Acid, 1-Aminocyclopropane-1-Carboxylate deaminase and cytokinin in response to plants root phytohormones [14]. In the current study, we noticed high $\mathrm{Ca}$ and $\mathrm{Na}$ in soil inoculated with dead inoculum (negative control group, $\mathrm{C}-$ ). The $\mathrm{C}-$ poor-soil with no microbial or plant root enrichment remained stable for two months with high $\mathrm{Mg}$ and $\mathrm{Na}$ and high $\mathrm{Ca}$ compared to all the groups. Potting-soil was high in $\mathrm{Mg}$ and $\mathrm{Na}$ in comparison to all groups. In comparison, the positive control $\mathrm{C}+$ soil, inoculated with living microbial combination resulted in high $\mathrm{Ca}$ in poor-soil only and lower in $\mathrm{Mg}$, $\mathrm{Na}$. The soil CaMg ratio was higher than in all the groups indicating a healthy soil composition.

It seems that $\mathrm{Na}$ was the only element that increased in PGPB group, while another elements $\mathrm{Ca}$ and $\mathrm{Mg}$ increased associated with arbuscular mycorrhiza group alone or when combined with ectomycorrhiza or PGPB. The high soil Ca to $\mathrm{Mg}$ ratio increase mycorrhiza colonization [15] and plant productivity [16]. It has been found that low soil $\mathrm{Ca}$ to $\mathrm{Mg}$ ratio cause plant premature root senescence and affect mycorrhiza colonization adversely [15]. The increase in soil Ca and $\mathrm{Mg}$ with stable high ratio for $\mathrm{Ca}$ associated with $\mathrm{AM}$ group alone or when combined with PGPB. Ca is a signaling element bound to specific receptors between plant root cells and microorganisms [17]. The increase of Ca in all the AM inoculated soil groups indicated its importance in plant root and arbuscular mycorrhiza communication to facilitate colonization [17].

The arbuscular mycorrhiza combination with PGPB increased $\mathrm{Ca}$ and $\mathrm{Mg}$ in presence of plants roots in comparison with positive control. The positive control group, which contained active microbes, was lower in these two elements ( $\mathrm{Ca}$ and $\mathrm{Mg}$ ) since this group lack plant root system. The need of plant and soil microbes' interaction is essential to rhizosphere health and ecosystem stability.

\section{References}

[1] Koorem, K., Gazol, A., Öpik, M., Moora, M., Saks, Ü., Uibopuu, A. and Zobel, M. (2014) Soil Nutrient Content Influences the Abundance of Soil Microbes but Not Plant Biomass at the Small-Scale. PloS One, 9, e91998. 
https://doi.org/10.1371/journal.pone.0091998

[2] Dhawi, F., Datta, R. and Ramakrishna, W. (2015) Mycorrhiza and PGPB Modulate Maize Biomass, Nutrient Uptake and Metabolic Pathways in Maize Grown in Mining-Impacted Soil. Plant Physiology and Biochemistry, 97, 390-399.

https://doi.org/10.1016/j.plaphy.2015.10.028

[3] Park, Y.S., Dutta, S., Ann, M., Raaijmakers, J.M. and Park, K. (2015) Promotion of Plant Growth by Pseudomonas Fluorescens Strain SS101 via Novel Volatile Organic Compounds. Biochemical and Biophysical Research Communications, 461, 361365. https://doi.org/10.1016/j.bbrc.2015.04.039

[4] Dhawi, F. (2016) Mycorrhiza, Bacteria and Plant an Organized Model of Rhizoshere Interaction. International Journal of Scientific \& Engineering Research, 7, 61-77.

[5] Dhawi, F., Datta, R. and Ramakrishna, W. (2016) Mycorrhiza and Heavy Metal Resistant Bacteria Enhance Growth, Nutrient Uptake and Alter Metabolic Profile of Sorghum Grown in Marginal Soil. Chemosphere, 157, 33-41. https://doi.org/10.1016/j.chemosphere.2016.04.112

[6] Duponnois, R., Kisa, M., Assigbetse, K., Prin, Y., Thioulouse, J., Issartel, M., Moulin, P. and Lepage, M. (2006) Fluorescent Pseudomonads Occurring in Macrotermessubhyalinus Mound Structures Decrease Cd Toxicity and Improve Its Accumulation in Sorghum Plants. Science of the Total Environment, 370, 391-400. https://doi.org/10.1016/j.scitotenv.2006.07.008

[7] Sebuliba, E., Nyeko, P., Majaliwa, M., Eilu, G., Kizza, C.L. and Ekwamu, A. (2012) Enhanced Growth of Multipurpose Calliandra (Calliandracalothyrsus) Using Arbuscular mycorrhizal Fungi in Uganda. The Scientific World Journal, 2012, Article ID: 830357. https://doi.org/10.1100/2012/830357

[8] Borde, M., Dudhane, M. and Jite, P. (2012) Growth, Water Use Efficiency and Antioxidant Defense Responses of Mycorrhizal and Non Mycorrhizal Allium sativum L. under Drought Stress Condition. Annals of Plant Sciences, 1, 6-11.

[9] Blaudez, D., Jacob, C., Turnau, K., Colpaert, J.V., Ahonen-Jonnarth, U., Finlay, R. and Chalot, M. (2000) Differential Responses of Ectomycorrhizal Fungi to Heavy Metals in Vitro. Mycological Research, 104, 1366-1371.

https://doi.org/10.1017/S0953756200003166

[10] Kannan, V.R., Suganya, S., Solomon, E.K., Balasubramanian, V., Ramesh, N. and Rajesh, P. (2011) Analysis of Interaction between Arbuscular mycorrhizal Fungi and Their Helper Bacteria by MILPA Model. Research in Plant Biology, 1, 48-62.

[11] Motsara, M. and Roy, R.N. (2008) Guide to Laboratory Establishment for Plant Nutrient Analysis. Food and Agriculture Organization of the United Nations, Rome.

[12] Mukerji, K.G., Manoharachary, C. and Singh, J. (2006) Microbial Activity in the Rhizosphere. Springer Science \& Business Media, Berlin/Heidelberg. https://doi.org/10.1007/3-540-29420-1

[13] Phillips, A.J., Gerlach, R., Lauchnor, E., Mitchell, A.C., Cunningham, A.B. and Spangler, L. (2013) Engineered Applications of Ureolyticbiomineralization: A Review. Biofouling, 29, 715-733. https://doi.org/10.1080/08927014.2013.796550

[14] Gupta, S.K. and Goyal, M.R. (2017) Soil Salinity Management in Agriculture: Technological Advances and Applications (Innovations in Agricultural \& Biological Engineering). CRC Press, Boca Raton.

[15] Jarstfer, A.G., Farmer-Koppenol, P. and Sylvia, D.M. (1998) Tissue Magnesium and Calcium Affect Arbuscular mycorrhizal Development and Fungal Reproduction. Mycorrhiza, 7, 237-242. https://doi.org/10.1007/s005720050186 
[16] Simson, C.R., Corey, R.B. and Sumner, M.E. (1979) Effect of Varying Ca: Mg Ratios on Yield and Composition of Corn (Zea mays) and Alfalfa (Medicago sativa). Communications in Soil Science \& Plant Analysis, 10, 153-162. https://doi.org/10.1080/00103627909366885

[17] Navazio, L. and Mariani, P. (2008) Calcium Opens the Dialogue between Plants and Arbuscular mycorrhizal Fungi. Plant Signaling \& Behavior, 3, 229-230.

https://doi.org/10.4161/psb.3.4.5093

\section{Scientific Research Publishing}

Submit or recommend next manuscript to SCIRP and we will provide best service for you:

Accepting pre-submission inquiries through Email, Facebook, LinkedIn, Twitter, etc. A wide selection of journals (inclusive of 9 subjects, more than 200 journals)

Providing 24-hour high-quality service

User-friendly online submission system

Fair and swift peer-review system

Efficient typesetting and proofreading procedure

Display of the result of downloads and visits, as well as the number of cited articles

Maximum dissemination of your research work

Submit your manuscript at: http://papersubmission.scirp.org/

Or contact oje@scirp.org 